Gender, age and the MBA: An analysis of extrinsic and intrinsic career benefits

Professor Ruth Simpson

School of Business and Management

Brunel University

Uxbridge

Middlesex, UB8 3PH

Email: r.simpson@ brunel.ac.uk

Dr Jane Sturges

The Management Centre

Kings College, London

Email: Jane.Sturges@kcl.ac.uk

Professor Adrian Woods

Brunel University

Email: adrian.woods@brunel.ac.uk

Professor Yochanan Altman

London Metropolitan

Email: Y.Altman@unl.ac.uk 


\begin{abstract}
Against the background of an earlier UK study, this paper presents the findings of a Canadian based survey of career benefits from the MBA. Results indicate firstly that gender and age interact to influence perceptions of career outcomes (young men gain most in terms of extrinsic benefits of career change and pay), and secondly that both men and women gain intrinsic benefits from the MBA. However, intrinsic benefits vary by gender: men in the study were more likely to say they gained confidence from having a fuller skill set while women were more likely to say they gained confidence from feelings of self worth; men emphasised how they had learned to give up control while women argued that they had gained a 'voice' in the organization. The role of the MBA in career self- management and the acquisition of key skills are examined as well as the implications for the design of programmes in meeting the varied need of men and women in different age groups.
\end{abstract}




\section{GENDER, AGE AND THE MBA: AN ANALYSIS OF EXTRINSIC AND INTRINSIC CAREER BENEFITS}

Women have moved into the labour market in increasing numbers and this increase is particularly marked in management. In Canada and the UK, the two countries at the center of this study, the proportion of women in management has risen steadily. Between 1971 and 1997, figures have risen from 16\% to 33\% in Canada (Statistics Canada, 1997) and 9\% to $28 \%$ in the UK (Labour Force Survey, 1997). In both countries and in most sectors, men outnumber women at higher management levels: for example, at board and director level recent figures suggest that in Canada only 6\% are women (Catalyst, 2000a) and 5\% in the UK (Institute of Management, 1996).

One strategy men and women adopt to move into the higher levels of management is to equip themselves with an MBA. This has been noted both in Canada (Burke, 1994) and the UK (Goffee \& Nicholson, 1994; Simpson \& Altman, 2000). Women now account for one third of MBA students in the UK and Canada (AMBA, 1997; Business Week, 1997) and the figure for the US - the largest MBA market in the world, is similar (Catalyst, 2000b). The MBA is viewed by many as a worthwhile investment and the increase in the number of MBA programmes in North America and Europe is indicative of the perceived benefits of the qualification (Business Week, 1997). However, despite the popularity of the MBA, little is known about the nature of these benefits and how they might vary by gender.

This paper addresses the above research gap by considering gender differences in career benefits from the MBA. Against the background of an earlier (1996) UK survey of MBA graduates, it draws on data from a follow up study, conducted in 2000, of 225 MBA graduates from a leading business school in Ontario, Canada. Results from the UK survey, based on data 
from eleven business schools and a total of $221 \mathrm{MBA}$ graduates, indicate benefits from the MBA may vary along gender lines. The data suggests that while the men may be more likely to gain extrinsic benefits in terms of pay, status and marketability, women may be more likely to perceive that they gain intrinsic benefits such as increased confidence, enhanced credibility and more effective interpersonal skills (Simpson, 1995; 1996; 2000b). The present study in Canada was set up to explore the generalizability of this phenomenon by exploring MBA benefits in a different national and academic context.

\section{THE MBA IN CANADA}

While the first MBA programmes were introduced in the US, courses soon became established in Europe and Canada. With nine of its twenty six business schools in the 2001 Financial Times listing of the top 100 international MBAs and with four in the top 50, Canada now has a well established MBA provision. The decline in demand experienced in the early 1990s, as students turned to more prestigious US and European universities, has been largely reversed - helped by the growing reputation of Canadian schools and by new initiatives including strategic alliances with the US (e.g. the new EMBA provided jointly by Schulich Business School in Canada and Kellogg in the US). As one of the top business schools in Canada (Business Week, 2000), the university from which this sample was drawn has a sound reputation and the potential to give its graduates a strong 'MBA advantage'. Canada's more pro-active and interventionist approach to equality initiatives, as evidenced by an emphasis on affirmative action rather than equality of opportunity common in the UK (Gunderson, 1994a, 1994b), may mean this advantage could be more equally shared between men and women than was the case in the UK. The gender gap in pay, for example, tends to be lower in Canada, where women earn on average 85\% of men's weekly pay (Statistics Canada, 2002), than in the UK where the comparable figure is $75 \%$ (Labour Force Survey, 2002). In addition, Ontario (the 
location of the study) has been identified as having possibly the most far-reaching equity initiatives laws in North America (Smeenk, 1993). The background of this study consequently provided an opportunity to assess whether gender differences, similar to those that emerged from the UK study, might also exist for graduates from a high ranking business school (Business Week, 2000) as well as from a national culture in which more official policies have been initiated and supported to promote women in management.

\section{EXTRINSIC AND INTRINSIC CAREER BENEFITS}

Management theorists have used the concepts of intrinsic benefits (job satisfaction and fulfillment) and extrinsic benefits (pay and status) to evaluate rewards that managers and other workers expect from employment (e.g. Marshall, 1984; Nicholson \& West, 1988; Scase \& Goffee, 1989; Young, Worchel \& Woehr, 1998). Young et al. used a five fold measure of intrinsic rewards to include job characteristics (autonomy, feedback and skill variety), communication (openness of information), leader satisfaction (relationship with supervisors), job satisfaction (enjoyment of job activities) and intrinsic exchange (levels of appreciation for good job performance). In a broader analysis, Scase and Goffee examined levels of remuneration, opportunities for promotion, security and personal status of managers as extrinsic rewards with intrinsic factors including opportunities for decision making, task discretion, autonomy and self fulfillment while Marshall (1984) additionally includes the quality of working relationships with same status and more junior workers. Adopting the above interpretation, Marshall (1984) and Nicholson and West (1988) suggest gender differences in career rewards (discussed below) with men gaining more extrinsic and women more intrinsic career benefits.

As in the UK survey, this study adopts a similar dichotomy in analyzing outcomes from the MBA. Extrinsic benefits are therefore taken to include the more objective career 
advantages such as progression and pay. Intrinsic benefits are taken to include intrinsic rewards from the job (e.g. job satisfaction) as well as more subjective outcomes relating to self-development (confidence, credibility, and enhanced self- worth) and interpersonal skills (leadership/team working abilities, communication and listening skills). While such skills may not fit easily into a categorization of career benefits, they were incorporated into intrinsic outcomes on the grounds of their likely contribution to many of the stated components above. For example, leadership and team-working abilities as well as communication and listening skills may well enhance the quality of working relationships including relationships with supervisors. In fact, using coefficient alpha on the survey data, strong internal consistency reliability emerged on constructed extrinsic and intrinsic scales $(\alpha=.92$ and $\alpha=.76$ respectively) where the latter included confidence, credibility, job satisfaction, team management and team working skills. However, because of lack of fit with the extrinsic/intrinsic dichotomy, 'hard' skills i.e. the specific management skills taught within the course such as data/ financial analysis and information technology (IT) skills, are treated as a separate category.

\section{THE BENEFITS OF THE MBA}

Research from the US, Canada and the UK indicate important extrinsic benefits from the MBA. A survey conducted by the Association of MBAs (AMBA) in the UK in 1996 found that after qualification the proportion of participants in senior management nearly doubled and there was a fourfold increase in those involved in senior roles such as corporate strategy and planning (AMBA, 1997). Data from the US suggest comparable career improvements in terms of seniority of position and business start-ups (Messmer, 1998) with the vast majority (95\%) of male and female MBA graduates from the 12 top business schools in the US expressing satisfaction with their subsequent career progress (Catalyst, 2000b). 
Data from Canada paints a similar picture, pointing to a strong 'MBA advantage'. Business Week (1997), for example, has indicated that graduates from the top Canadian business schools can expect to recoup their investment within two years through promotions and increased pay. Consequently, many men and women perceive the MBA to be a passport to success in terms of increased salary and enhanced career progress and, as Baruch and Peiperl (1999) suggest, increasingly see the qualification as a pre-requisite for many senior management posts.

In terms of gender, much of the work on MBAs and career progress comes from the US where results suggest that women do not progress as far or receive the same level of remuneration as men. A recent report by Catalyst (Catalyst, 2000b) indicates that men have advanced further than women in both line positions and reporting span and that while men and women are equally likely to value the MBA in terms of their careers, men are significantly more likely to be satisfied with their career advancement after completion of their course than women. Similarly, Cox and Harquil (1991) found that while there was no significant difference between men and women in terms of career satisfaction, women MBAs had significantly fewer management promotions. Moreover, salary growth for women was still significantly smaller than for men even after controlling for performance, age, experience, starting salary and career paths - a gap that may well increase over time (Schneer \& Reitman, 1990; 1995). Comparable findings on gender disparities in 'the MBA effect' emerged from the UK study (Simpson, 1995; 1996). Men were more likely to move into senior roles after the MBA, to progress via an internal labour market and to receive larger salary increases (the salary gap between men and women actually widened after the course). Thus:

Proposition One 
After completion of the MBA, men gain more than women in terms of extrinsic benefits (number of promotions, increased management status, career change, higher pay).

However, while evidence supports the view that, for men at least, the MBA is associated with rapid career advancement, the issue of the nature of other benefits (e.g. skills, capabilities) received remains somewhat sketchy. Kretovics (1999), in a US based study of the learning outcomes of an MBA programme, found that the MBA added value in key areas such as information analysis, sense making and initiative but not in interpersonal or communication skills. Similarly, Boyatzis and Renio (1989) suggest that attending an MBA programme adds value on a number of abilities related to effective managerial performance but not on interpersonal and leadership abilities. This is despite the increased emphasis on ‘managerial fitness' (Kakabadse \& Kakabadse, 1999) i.e. the maturity, self awareness and empathy required to make high quality decisions - and on communication and leadership skills as critical for success in the workplace. In fact, according to Shipper (1999), the MBA does not provide an advantage in key managerial or leadership skills over those who possess only a bachelor's or some other master's degree. Similarly, Pfeffer and Fong (2002) and Mintzberg and Gosling (2002) argue that business education places too much emphasis on the functions of management at the expense of the 'practice of managing' and its associated leadership, interpersonal and communication skills.

While the above studies indicate the MBA may be less effective in the formation of important interpersonal or leadership skills, the issues of how such skills and other benefits might vary by gender is not addressed. Work on conceptualisation and career success among male and female managers and professionals indicates that gender is a strong influencing factor: men are likely to prioritise salary and status while women tend to see career success 
more as a process of personal development through interesting and challenging work (Burke and McKeen, 1994; Marshall, 1984; Nicholson and West, 1988; Powell \& Maniero, 1992; 1993; Russo, Kelly \& Deacon, 1991; Sturges, 1999). This may reflect the presence of career barriers which encourage women to focus on the intrinsic rewards of the task at hand rather than on the uncertainties of pay and status (Marshall, 1984; Nicholson \& West, 1988). These differences in career orientation may well influence the nature of perceived career benefits from the MBA - a view supported by results from the UK study of MBA graduates. These results indicate that men and women may benefit differently from the MBA along the lines discussed above. While men tended to gain extrinsic benefits of increased salary and managerial status, for women the benefits were likely to be more intrinsic in the form of enhanced confidence, credibility and job satisfaction. During interviews, men and women stressed the credential value of the course by emphasising enhanced marketability and mobility while women additionally valued the experience of the MBA in altering their perceptions of themselves, of their organization and of their work colleagues. Women were more likely to describe the MBA as an 'eye-opening' experience which encouraged self confidence and self belief and which gave them greater credibility within the organizational context. A similar finding emerged from Hilgert's (1998) study of six women graduates from an executive MBA programme where the MBA experience was associated with a "new understanding of the world' and a 'life-changing' outcome. Within the context of the UK study, men were less likely to discuss such changes. Thus

\section{Proposition Two:}

After completion of the MBA, women gain more than men in terms of intrinsic benefits and skills (confidence, credibility, assertiveness, job satisfaction, interpersonal and communication skills) 
Important connections can be made between these propositions and recent literature on careers. In a survey of such literature, Martin and Butler (2000) found widespread agreement of the rise of 'boundaryless' or 'protean' careers. These conceptualise a 'new deal' whereby people take consensus that the traditional career (where salary, status and a secure career ladder within a single organization are exchanged for loyalty and commitment) may be giving way to new responsibility for their own career management in a more uncertain environment (Hall \& Mirvis, 1996), where career paths go beyond the boundaries of a single organization (Hall, 1996) and where there is an emphasis on portable skills and on meaningful work (Hall \& Mirvis, 1996). Such developments in career structures are likely to have important gender implications. As Fondas (1996) and Ensher, Murphy and Sullivan (2002) suggest, women's experiences and priorities may be more in line with the new career. These experiences, perhaps due to career barriers and/or care-taking responsibilities, involve career interruptions, 'outspiralling' moves and sudden changes in direction that are characterisitc of the uncertainties inherent in the 'new career' environment (Burke \& McKeen, 1993; Nicholson \& West, 1988). According to Fondas, the combination of these experiences with the foregrounding of shared cooperation, empathy and flexibility, culturally associated with femininity, may make women better suited than men to boundaryless or protean careers in contemporary organizational contexts where team skills and relationships are emphasised. Accordingly, as Schneer and Reitman (2003) found in a study of MBA graduates, women managers on protean career paths may be more likely than women with more traditional 'organizational' careers to achieve equality with male counterparts, suggesting that protean careers may help facilitate women's progress.

From this new career perspective, the MBA may have a pivotal role for men and women in facilitating career development and as a means of acquiring a range of portable 
skills that are essential in the new boundaryless career environment. As we have seen, career development of men and women may differ post MBA and there may be differences in the range of skills men and women bring to the workplace including skills acquired from the MBA. This is captured by the two propositions on which this research is based. Given the limited data on skills and benefits from the MBA - particularly in relation to gender differences - it is important to assess the success of the qualification in fulfilling these and other roles.

\section{RESEARCH METHOD}

Quantitative methods, comprising stage one of the project, were used to establish the personal and work profiles of MBA graduates, career progress and the nature of skills and benefits from the MBA process. Data on skills and benefits was also drawn from stage two of the project in the form of in-depth interviews. The sample was drawn from a leading business school in Ontario, nearly all of whom (90\%) had received their degrees between 1997 and 1999. Six hundred questionnaires were sent to MBA graduates through the alumni association. A total of 225 questionnaires were returned, a response rate of $36.8 \%$ - within the accepted response rate in management scholarship (Roth and BeVier, 1998; Baruch, 1999). Of these, two thirds (63\%) were male and one third (37\%) female. The sample comprised roughly equal proportions of full time and part time /executive students.

The questionnaire covered three key areas. The first section, About You, aimed to gather information on the profile of the MBA graduate in terms of age, qualifications, marital status, children and the impact of children on careers. The second section, Your Employment and the $M B A$, sought information concerning career progress e.g. change in function, role and pay; number and nature of promotions, career prospects. In order to reduce the effect of time in the labour market on career progress, a restricted sample comprising those respondents 
who gained their MBA in 1997, 1998 and 1999 was used in career change analysis (i.e. those who received their MBA prior to 1997 were excluded). The final section Benefits and Skills from the $M B A$ explored a range of benefits (e.g. greater marketability, enhanced job prospects, enhanced confidence) and skills (e.g. handling complex data, managing teams, negotiation skills) on 5-point Likert type scales.

As the data was predominantly nominal the chi square test was used as an appropriate non parametric statistical technique. The F test was used when one of the variables was nominal (e.g. gender) and the other ordinal (e.g. scales of benefits and skills). To gain a preliminary understanding of the key predictors of MBA outcomes, chi square automatic interaction detector (CHAID), as discussed by Kass (1980) and Bigg, De Ville and Suen (1991), was applied. From this it became clear there was an interaction between age and gender for most of the outcomes tested. Consequently, a new variable that broke the respondents into four age/gender groups (females aged under 35, males aged under 35, females aged 35 and over, males aged 35 and over) was constructed for further analysis of MBA outcomes. The cut-off age of 35 was chosen as the transtitional turning point between career establishment and career ascension, as discussed by Evans (1986) and Altman (1997).

Respondents were asked to provide name and contact details if they were willing to be interviewed. An interview sample (14 women and 11 men) was then drawn up on the basis of accessibility (the location of Ontario) and availability (the researchers were in Canada for only two weeks to undertake interviews). Three of the named authors conducted the interviews. In order to gain an 'authentic' understanding of graduates' perceptions of benefits from the MBA (Silverman, 1993), semi-structured interviews were used. Each graduate was interviewed for approximately one hour, giving respondents the opportunity to reflect on the outcomes of the MBA. Graduates were asked about their motives for taking the MBA, their 
career history and career progress. In addition they were asked to reflect on the nature of skills and benefits acquired, the skills/benefits they valued most and those which had been most useful to them in their post-graduate careers. The latter topics were explored in some depth with the aim of supplementing section three of the questionnaire (Skills and Benefits from the MBA). Interviews were recorded and later transcribed.

Data was analysed using content analysis as discussed by Remenyi (1992), Jankowicz (1991) and Holsti (1968). This is defined as "any technique for making inferences by systematically and objectively identifying special characteristics of messages" (Holsti, 1968, p. 608). On this basis, outcomes of the MBA were used as the 'criteria of selection' (Bruce and Berg, 2001). These were identified from the analysis of transcripts and a comprehensive list of skills and benefits was constructed. Twenty five outcomes were identified in this way and these were divided into extrinsic and intrinsic benefits as discussed above. A separate category was made to include hard skills (e.g. data analysis, financial skills, IT skills). An initial count was made of respondents who had considered each item to be an outcome of the MBA and recorded on a matrix. The matrix, divided by gender, charted the frequency of stated benefits (e.g. increased confidence) and their nature (e.g. confidence through enhanced skills, confidence through self esteem).

While the frequency of occurrence of concepts was thus taken into consideration, so also were their saliency and their relationship to each other. As Ritchie and Spencer (1994) point out, the process of qualitative data analysis is not simply the aggregating of patterns or a reliance on a multiplicity of evidence but additionally includes the weighing up of the salience and dynamics of issues. According to Bruce and Berg (2001), content analysis can be applied to 'manifest content' i.e. those elements that are physically present and countable as well as to 'latent content' i.e. an interpretive reading of the symbolism underlying the 
physical data. Accordingly, the researchers interpreted the salience and significance of outcomes, a process referred to as 'deciphering' (Heilman, 1976). Such interpretations were made by two of the three researchers involved in the interview process. Data was analyzed separately and then corroboration given to emerging themes by comparing/discussing individual interpretations and highlighting areas of commonality. Such a technique of independent analysis followed by collaborative scrutiny and discussion was recommended by Heilman (1976) as a means of increasing the reliability of content analysis. Agreement was reached when at least three excerpts were identified from relevant statements that served to document the researchers' interpretations. This has been offered as a safe 'rule of thumb' for reliability in latent content analysis (ibid).

\section{RESULTS FROM THE SURVEY DATA}

\section{General Profile}

Some statistically significant differences emerged in terms of the profile of male and female MBA graduates. Women in the sample tended to be younger (Chi square: 2.792, $\mathrm{P}=$ 0.095) and were less likely to be married (Chi-square: 6.319, $\mathrm{P}=0.097)$ or to have children (Chi square: $11.626, \mathrm{P}=0.02$ ) than men. One fifth of women with children and $11 \%$ of men with children felt their child care responsibilities had 'adversely affected' their careers (Chisquare: $9.089, \mathrm{P}=0.059)$.

The majority of both men and women had a bachelor's degree as their highest qualification prior to the MBA with the largest concentrations in Business/Management (41.3\%) followed by Science/Engineering (34.6\%) and Arts/Humanities (24\%). Gender differences in terms of subject of first degree were not significant. While there was an even split in the sample between those who had taken full time and part-time/executive modes of study, and a fairly even split for men between the two modes, two thirds of women had taken 
their MBA on a full time basis (Chi square: $11.843, \mathrm{P}=0.001$ ). The full time mode also attracted younger respondents: $90 \%$ of females and $78 \%$ of males under 35 studied full time compared with $28 \%$ of older women and $10 \%$ of older men (Chi square: $105.345, \mathrm{P}=0.001$ ).

Sixty percent of the men and fifty percent of the women worked in organizations of over 1,000 employees and three quarters of both men and women were working in the private sector at the time of the survey. The largest concentrations were in finance (32.8\%), consultancy (16.4\%), computing (11.4\%) and manufacturing (12.4\%). Gender differences were not significant. Nearly one half of respondents had been in their present position for less than one year and three quarters felt they had remained in their present position the time they had anticipated. However, while there were no significant differences by age or by gender in the length of time respondents had remained in their current job, younger women were more likely than younger men to feel they had spent too long in their present position and older women were more likely than older men (and more likely than any other group) to feel this way (Chi square: 13.198, $\mathrm{P}=0.040)$.

The most popular reason for taking the MBA was to improve job opportunities (35.8\%) followed by the desire for a career change (23.5\%), for a business/academic qualification (16.3\%) and for intellectual stimulation (15.4\%). The least popular choice was the desire to obtain general skills. Very few $(2.3 \%)$ chose increased salary as a motive for taking the MBA. Age/gender differences were examined for the four most popular choices (improve job opportunities, change career direction, obtain business qualification and intellectual stimulation). Results are summarised in Table 1. Younger women stand out in wanting a career change (38.8\%), while younger men and older women were motivated by a desire to improve job opportunities (50\% and 53.6\% respectively). Older men were more likely than any other group to be motivated by intellectual stimulation (27.7\%). 
Table 1 here

\section{Career Change and Career Progress}

About a half of men and women changed function after the MBA with higher proportions for younger age groups: two thirds of those under 35 changed function compared to only $43 \%$ of those aged 35 or over (Chi square: $7.599, \mathrm{P}=0.006)$. Younger men stand out as the most mobile group: two thirds changed function compared to $58 \%$ of younger and $44 \%$ of older women. With only $39 \%$ changing function, the least mobile group was older men (Chi square: $8.286, \mathrm{P}=0.040$ )

Three quarters of men and women changed roles after the MBA - with the largest move from middle/junior/technical roles into senior management. Gender differences in role before and after the MBA were not significant. Not surprisingly, older respondents were significantly more likely to be in senior roles than younger respondents. Over a half (58\%) of older men and women were in senior roles post MBA compared with $33 \%$ of younger males and $24 \%$ of younger females (Chi square: $28.487, \mathrm{P}=0.000$ ). Approximately $40 \%$ of men and women had achieved one promotion since graduating with their MBA and one fifth had achieved two promotions. There were no significant gender, age or age/gender differences in terms of number of promotions post MBA.

Looking at the nature of career progress, one fifth had changed career, just under a third $(28 \%)$ had progressed within their existing organization and one third $(28 \%)$ had changed organization in order to progress. Neither gender nor age was significantly associated with career progress. However, further analysis revealed a significant age/gender effect. Younger men were the most mobile in terms of changing careers (33\%) and the least mobile group was older men $(7.1 \%)$. Younger women stand out in that they were significantly more likely than any other group to have had no change in career since gaining their MBA $(20.8 \%)$. 
None of this latter group had child-care responsibilities. The full report is shown in table 2 below.

Table 2 here

Some gender and age differences occurred in terms of pay. Before the MBA, age was a critical factor with older workers receiving higher pay than younger workers (Chi square: 86.799, $\mathrm{P}=0.000)$. After the MBA, however, age and gender were both significant. Older respondents were more likely than younger respondents to be in the highest pay bracket (Chi square: $15.291, \mathrm{P}=0.000)$. Similarly, men were more likely than women to be in the highest pay bracket (Chi square: $12.532, \mathrm{P}=0.002)$. Age/gender effects with pay reveals the following.

Table 3 here

As the above table illustrates, two major sources of disparity emerge. Firstly, younger women are disproportionately represented in the lowest pay category (23\% of younger women and only $6 \%$ of younger men earn under $\$ 60,000$ after the MBA). Secondly, at the other end of the scale, older women are much less likely than older men to be in the top pay category ( $35 \%$ of women and $70 \%$ of men). In fact it is older males that stand out in this pay bracket. Interestingly about the same proportion (one third) of younger women and younger men earn over $\$ 100,000$.

Looking at how pay had changed for different groups before and after the MBA, younger men emerged as the most dynamic group. One quarter of younger men and only $16.7 \%$ of younger women moved from pay category 1 (under $\$ 60,000$ ) to pay category 3 (over $\$ 100,000)$. At the same time, a larger proportion of younger women (23.8\%) remained in pay category 1 after the MBA compared with only $6 \%$ of younger men. Older workers 
experienced less dynamic pay changes - partly because they were already in higher pay categories. One half of older men (50.9\%) and one fifth of older women $(21.7 \%)$ changed from pay category $2(\$ 60-100,000)$ to 3 (over $\$ 100,000)$. (Chi square: $126.443, \mathrm{P}=0.000)$

\section{Benefits from the MBA}

In terms of career benefits, the most popular choices were greater marketability, enhanced job prospects, enhanced salary or status and enhanced credibility and confidence (see table 4 below)

Table 4 here

There were no significant gender differences. However, some age and age/gender differences emerged with respect to salary/status, confidence and credibility. Younger men and women were more likely to claim enhanced salary and status as a benefit from the MBA of the 14 respondents aged over 45 only one reported this benefit "to a great extent" compared to $23 \%$ of the $35-44$ year olds and $38 \%$ of the $25-34$ year olds (Chi square: 25.768 , $\mathrm{P}=0.001)$. Younger males (under 35$)$ were most likely (47\%) and older males (35 and over) least likely $(16 \%)$ to claim this as a benefit (Chi square: 22.291, $\mathrm{P}=0.034)$. In terms of confidence, older respondents (57\% of those over 45$)$ were more likely than younger respondents (17\% of those aged between 25 and 34) to feel they had benefited in this way (Chi square: 15.283, $\mathrm{P}=0.054)$. Finally, compared to the rest of the sample, younger males (under 35) were less likely to claim enhanced credibility from the MBA: 19\% compared to $30 \%$ for the rest of the sample (Chi square: 9.343, $\mathrm{P}=0.053$ ).

Benefits were then grouped together to form 'extrinsic benefits' (including marketability, job prospects, enhanced salary) and 'intrinsic benefits' (including enhanced confidence, credibility, job satisfaction and interpersonal skills). For both, a scale was formed 
by adding the scores of the variables together with 1 representing strongly agree through to 5 strongly disagree (extrinsic benefits: Cronbach alpha $=0.9215$; intrinsic benefits: Cronbach alpha $=0.7568)$.

There were no significant age, gender or age/gender differences with respect to extrinsic benefits - though some age/gender differences emerged with intrinsic benefits.

Older women compared to all other respondents emerged as most likely $(\mathrm{F}=4.903 ; \mathrm{P}=0.028)$ and younger men, compared to all other respondents least likely $(\mathrm{F}=3.630 ; \mathrm{P}=0.058)$ to value intrinsic benefits highly. Comparing younger males with older females, the latter were much more likely to have reported gaining intrinsic benefits $(\mathrm{F}=6.549 ; \mathrm{P}=0.012)$.

\section{Skills}

In terms of skills, the two most popular choices were the ability to handle and analyse complex data and negotiation skills. The least popular choice was sensitivity to difference and diversity (see Table 5 below).

Table 5 here

Gender differences were not significant. However, an age/gender effect emerged in terms of assertiveness. Older women stand out in valuing this as a skill gained from the course: three quarters of older females compared to $47 \%$ of younger males and females, and $39 \%$ of older males claimed they had gained this as a skill 'to a large extent' (Chi square: 15.182, $\mathrm{P}=0.019)$.

\section{RESULTS FROM INTERVIEW DATA}

In accordance with the survey data, most of the interviewees' motives for doing the MBA were extrinsic (e.g. career advancement, job opportunities). Almost all of the interviewees believed that they had progressed in their careers after completing their MBA 
(eight women and two men had changed career completely) and that they had benefited from acquiring a set of hard skills, in particular financial and data analysis. However, intrinsic benefits, such as increased confidence and credibility, emerged as highly important for the majority of the research participants. In addition, many of the women interviewed discussed gender as an issue and were critical of what they perceived to be the 'male ethos' of the course.

\section{Intrinsic Benefits}

Intrinsic benefits identified related to greater confidence and enhanced interpersonal skills in both internal and external work relationships.

\section{Confidence}

The most crucial benefit of the MBA acknowledged by all the interviewees was an increase in self- confidence. Closely aligned to this was improved credibility through being 'hallmarked' by the MBA. Analysis showed that there were two separate groups in terms of how they explained this increase in self-confidence. One group (predominantly male: 9 men and 2 women) believed that their confidence had grown as a direct result of the 'hard' skills they had acquired on the course. This is captured by the following comments:

I'm certainly more confident now...I think doing the course has had an impact on what I perceive my overall skills to be. (male graduate)

It wasn't about confidence in general but about confidence in a new area of skills...things that weren't necessarily part of my previous work experience. (male graduate)

Another group (predominantly female: 10 women and 2 men) attributed their increase in confidence to what might be described as 'the MBA experience'. This included feelings of 
achievement from succeeding in a difficult and demanding program (6 women, 1 man) feelings of self worth (9 women, 1 man) and empowerment through being able to openly voice opinions ( 8 women, 2 men). Six women expressed surprise and disbelief at what they had achieved: "it's opened doors to myself”; "it opened my eyes"; "it was unbelievable for me". One described her surprise at being in the top $10 \%$ of her class:

I never thought of myself as particularly bright. I always had to work hard for everything I got but I finished up on the Dean's List! That increased my confidence, having that official credential from an official body. (female graduate)

Nine women experienced a greater sense of self worth: "I feel better about myself"; "I'm more comfortable in my own skin"; "I'm more comfortable with who I am". Enhanced confidence and knowledge gained from the MBA gave women in particular the self-assurance to verbalize ("it helped me speak") - to make their views known, to put their ideas on the table in meetings and to discuss issues with senior staff.

I can put an idea on the table and have it move forward or adjusted or changedbut at least it gives them an idea of where I'm coming from because if I don't speak it they don't know. (female graduate)

I can hold a conversation (with the CEO) and hold his attention to it. (female graduate)

I'm more vocal because I have the foundations for it. (female graduate)

Therefore, while all MBAs commented on the enhanced confidence the MBA can bring, gender differences emerged in terms of the source of this confidence. For men this 
related more to the acquisition of a set of (largely hard) tools and skills while for women the source of confidence was more intrinsic relating to feelings of achievement, self worth and self-assurance.

$\underline{\text { Interpersonal Skills }}$

The majority of the interviewees reported improved team-working skills as a result of doing the MBA. This was acknowledged to be a consequence of the emphasis on group work in the course, an experience that was sometimes painful and difficult (as individual groups did not always work well) but in general beneficial. Empathy, communication and listening skills were important for women. Four women discussed how they were "more objective" "less emotional" "more detached" had "toughened up" as a result of their MBA. This was seen as useful when difficult decisions had to be made.

Gender differences emerged in terms of the nature of these skills. For men, interpersonal skills were largely discussed in terms of leadership. Nine men and only two women specifically referred to leadership and discussed leadership issues as outcomes in this respect. These related firstly to a perceived enhancement of leadership capabilities as a result of the MBA experience (6 men, 1 woman). However, this did not always translate into better management skills in terms of managing their own teams at work. Only four (all men) of the 15 interviewees who were staff managers claimed the MBA had helped them in this way. The remaining eleven felt the MBA had had no effect - either because such skills could only be learned by experience or because they were not addressed by the MBA program. The second leadership issue addressed by interviewees related to the capacity to 'let go' and give up control (6 men and 1 woman). This was closely associated with trust and the ability to delegate - as the following quotes illustrate:

It's a question of letting go sort of thing and not having control and trusting other 
people. (male graduate)

I think it's (the MBA experience) been relatively effective.... I think over time if you learn to trust people you can sort of release that ..grip on the project. (male graduate)

Before it was inconceivable that I would let someone else do something and put my name on it and trust them to do it as I intended. (male graduate)

Having to rely on somebody who you had absolutely no control over has been a good experience for me - however difficult. (male graduate)

While the MBA emerged as less effective in acquiring skills to manage down (i.e. in terms of managing individuals and teams), one large group ( 7 women, 5 men) reported that the MBA had equipped them to manage upwards and to deal more effectively with their bosses. Sometimes this was a consequence of increased confidence and assertiveness. For others, it sprang from a new awareness of the necessity to manage upwards and the acquisition of political skills enabling them to do so.

\section{Gender and the MBA}

Not surprisingly, gender was an important issue for women. While none of the men referred to gender (unless specifically asked about male/female experiences on the course) 10 women raised gender as an issue early in the interviews and without prompting. Difficulties of being female either in the context of the MBA course or at work were discussed as were detrimental male attitudes and the problems associated with the integration of family and work. Overall, women were more critical of the programme and this related mainly to what 
was perceived to be the 'macho' and competitive culture of the course. Women commented on the arrogant attitude and 'bravado' of male students and on their competitive behaviour referring to the typical MBA graduate (described by one female student as "Mighty Big Attitude") as, in their words, "aggressive", "competitive", "arrogant" and "overconfident". None of the men interviewed commented on the gendered nature of the MBA experience.

\section{DISCUSSION}

Proposition One:

After completion of the MBA, men gain more than women in terms of extrinsic benefits

(number of promotions, increased management status, career change, higher pay).

Results from the survey data conform with previous research (e.g. AMBA, 1997;

Catalyst, 2000b; Messmer, 1998) which suggest a strong 'MBA advantage' in terms of career progress and pay. However, unlike the mainly US research on gender and the MBA (Catalyst, 2000b; Cox \& Harquil, 1991; Roman, 1990) and in particular contrast to the UK study

(Simpson, 1995; 1996; 2000a; 2000b) it was gender with age rather than gender alone that is associated with significant differences in career progress. The survey data therefore only partially supports the above proposition.

Younger men gain more in terms of extrinsic benefits than any other group (they are the most mobile in terms of changing function and career and they achieve the greatest pay increase). Younger women are equally career focused: they also want career improvement and, in particular, career change - in conformance with career models that indicate high career investment for younger age groups (Clark, Oswald \& Warr, 1996; O’Connor \& Wolfe, 1987). Some younger women achieve their goals - moving on in terms of function, career change and pay - but a substantial number remain in the lowest pay scales and, despite their desire for a change, with no change in their careers. While child care responsibilities may be 
seen as a common career constraint, this is not the case for this childless group. This may suggest other barriers located within culture and practices of the organization along the lines discussed by Marshall (1984), Ibarra (1993) and Maddock and Parkin (1994).

Of the four age/gender groups, older men stand out in wanting intellectual stimulation in addition to career improvement and like older women they value the enhanced confidence from the MBA. Older women also have broader values - placing importance on intrinsic benefits (credibility, job satisfaction and interpersonal skills) in addition to career progress. This conforms with work which suggests that the importance of material success may lessen over time while the desire for a less tangible more personal kind of success increases (e.g. Lynn, Cao \& Horn, 1996; Marshall, 1995; Nicholson \& West, 1988).

Older men are the least mobile in terms of career and function change and, already on high pay scales, they are least likely to value salary and status as benefits from the MBA. Compared to the younger age groups, they gain modest increases in pay. As O'Connor and Wolfe (1987) suggest, men often reduce the investment in their careers as they get older as they move from the establishment/advancement stages to the maintenance stage of their careers (Hall, 1976; Lynn et al., 1996; Schein, 1978). This change may not be shared by older women, however, who often increase investment as they struggle to gain a career foothold after a period of family prioritisation or as a result of earlier career barriers (O’Connor \& Wolfe, 1987; Roberts \& Morgan, 1987). Accordingly, older women emerge from this study as more mobile than older men (though they benefit less in terms of pay). They are more likely than any other group to feel they had spent too long in their present position - possible evidence of a desire to effect a change (they form the majority of those women believing child care responsibilities had aversely affected their careers). There is little evidence - as in the case of younger women - of a 'non-mobile' or static group or of a career plateau that may 
characterise the careers of older men. This conforms with Powell and Maniero's (1992) ‘river of time' model. This conceptualises career development as currents of a river with career success on one river bank and success in relationships on the other. Women seek a balance but may move towards the 'emphasis on relationships' bank after starting their families while at a later stage, when children are older, may return to the 'emphasis on career' bank. In the context of this study, some older women may be at a stage of focusing on their careers - just at the time when older men are putting their priorities elsewhere.

Therefore, while men may be conforming to the traditional career model of early career building and mid career maintenance (Hall, 1976; Schein, 1978), for women the position is less clear-cut. Young women share with younger men an emphasis on extrinsic career benefits, but a substantial group experience little movement in terms of pay or career change. Some diversity also exists within the group of older women - both in terms of values and career outcomes - reflecting possible differences in career stages and priorities. This is resonant with Hakim's preference theory (Hakim, 2000) which suggests that women are more heterogeneous than men in their values and aspirations as they address in different ways the tensions between 'production and reproduction' as a central life activity.

Overall, the survey results suggest a greater gender convergence in career progress than was the case in the UK where large differences between men and women emerged. This may reflect the greater concentration of women in Ontario working in the private sector (in a city dominated by financial and other private sector institutions) where career paths are likely to be more dynamic. At the same time, the interventionist approach in Canada towards employment equity as discussed by Gunderson (1994a, 1994b), where the emphasis is more pro-actively on equality of outcomes rather than equality of opportunity as is the case in the UK, together with Ontario's particularly progressive approach in this respect (Smeenk, 1993), 
may well have reaped rewards in terms of assisting women's careers.

Proposition 2:

After completion of the MBA, women gain more than men in terms of intrinsic

benefits and skills (confidence, credibility, assertiveness, job satisfaction, interpersonal and communication skills)

The possibility that men prioritise extrinsic while women focus more on intrinsic career benefits has been raised by previous work (e.g. Marshall, 1984; Nicholson \& West, 1988; Powell \& Maneiro, 1992; 1993; Russo et al, 1991; Sturges, 1999). Similar gender differences in extrinsic and intrinsic skills and benefits from the MBA was suggested by the UK study which found that men placed greater value on enhanced job marketability and mobility over job satisfaction, enhanced credibility and the development of interpersonal skills, prioritised by women (Simpson, 1995; 1996; 2000a).

Two important outcomes have emerged from this study in relation to the above proposition. Firstly, the survey data suggests that it is age with gender, rather than gender alone, that is associated with differences in the extent to which graduates benefit 'intrinsically' from the MBA. Older MBAs are more likely to focus on intrinsic career factors than younger groups. At the same time, young men are least likely and older women most likely to claim intrinsic career benefits from the course. This conforms with work suggesting women have greater orientations towards intrinsic career rewards (e.g. Powell \& Maneiro, 1993; Russo et al, 1991; Sturges, 1999) and that for both sexes, these orientations become more important with age (Clark et al., 1996; O’Connor \& Wolfe, 1987).

Secondly, as the interview data suggests, both men and women gain intrinsic benefits from the MBA but they do so in different ways. Exceptions include enhanced confidence (discussed below) and the ability to deal confidently with bosses - seen as equally important 
by men and women. Such 'managing up' capabilities are important if, as Weick (1999) suggests, managers need to be able to 'speak up to power' and send information fast in an upward direction.

In terms of gender differences in intrinsic benefits, interview data indicate that for men the focus is largely on issues of leadership. This relates to a perceived improvement in leadership skills as well as to a new found ability to give up control through the development of trust in other team members. As Cianni and Wnuk (1997) indicate, team working frequently involves a tension between individual needs and team development and this can be resolved only if individuals 'give and take' in allocation of tasks, including leadership roles, and in the facilitation of learning. Integral to this process is the development of trust - a factor that has wider implications in terms of effective inter and intra firm collaboration (Weick, 1999). These results are important if it means that, as a result of the MBA, men experience a shift in what is often seen as a typically 'masculine' individualistic and directive approach (Collinson \& Hearn, 2000; Fondas, 1996; Hearn, 1994; Kerfoot \& Knights, 1993; 1998) to a more co-operative and supportive style.

Interview data suggests that both men and women claim an increased confidence from the MBA. However, gender differences emerged in the antecedents of such confidence. For men, perceptions of enhanced confidence were tied up with the acquisition of identifiable hard skills while for women confidence was seen to lead to several personal changes relating to feelings of achievement, greater self worth and a sense of empowerment. In relation to achievement, as Ohlott, Ruderman and McCauley (1994) suggest, overcoming obstacles can be a powerful developmental and affirming experience for women. Conquering lack of self confidence and coping with pressures from the course itself - as well as from possible family responsibilities - may therefore intensify feelings of triumph and personal success. 
Confidence also leads to a strong sense of self worth - and there is evidence to suggest that this encourages a "redrawing of mental boundaries" (Gunz et al, 2000, p.29) as women expand the range of options thought to be possible or achievable. Finally, confidence from the MBA experience was seen by many women to give them a 'voice' and a sense of empowerment. The concept of voice was first used by Hirschman (1970) to describe how, in a political or a market context, citizens and consumers articulate their critical opinions. More recently, the term has been used in a gendered context (e.g. Belenky, Clinchy, Goldberger \& Tarule, 1997; Gilligan 1982, Jansen \& Davis, 1998) to refer to how women - seen to lack voice - are excluded and silenced from the private and public realms. For Gilligan, women often lose voice and freedom of expression as the need to preserve relationships and protect others becomes paramount while, for Belenky et. al., acquiring a voice is intricately entwined with women's development of mind and of self in ways that have strong associations with the progress of female MBAs discussed above.

While the survey data indicates that young men may be least likely to benefit from intrinsic career factors (in partial support of the above proposition) what seems likely is that men and women bring different attitudes and levels of intrinsic skills to the MBA. They may therefore benefit differently in terms of this particular skill set. As Marshall (1984) suggests, women may be more 'tuned into' interpersonal skills (it is women who identify the empathy and listening skills required of an experienced and successful team worker and who are critical of the more individualistic and competitive attitudes of men) but they often lack confidence in their own abilities and self esteem. Changes in self perception as a result of the MBA experience may therefore have a critical impact on the opportunities they see open to them and on how they see their effectiveness at work. Men may also experience a shift, from a more individualistic, controlling style of working to one based on trust and co-operation, 
and this could be equally cathartic in terms of self evaluation and in creating the conditions for enhanced managerial performance.

\section{IMPLICATIONS FOR MANAGEMENT EDUCATION}

These findings raise important issues for management education. Firstly, while some people have argued that there are trends towards a 'feminisation' of both careers (e.g. Burke \& McKeen, 1994; Fondas, 1996) and of management (e.g. Fondas, 1993; Kanter, 1989; Lee, 1994), there is little sign that these trends have been reflected in the course content or design of the MBA. In terms of careers, as Fondas and Burke and McKeen point out, insecurity and frequent career shifts (previously characteristic of women's experiences) may be increasingly part of the 'new career' reality for men, less able to rely on steady increases in pay or predicable progression within a single organization. Similarly, the classical, 'masculine' notion of managerial work as consisting of "planning, ordering, directing and controlling" (Fondas, 1996: p.288; also see Alvesson, 1998; Collinson and Hearn, 2000; Kerfoot and Knights, 1993; 1998) is giving way to a need for cooperation, the building of relationships and responsiveness to others - culturally associated with femininity rather than masculinity (Alvesson, 1998; Kanter, 1989; Lee, 1994). Despite these possible trends towards feminisation, however, MBA course culture and design (as many of our female interviewees pointed out) remain largely masculine. This view supported by Sinclair (1995) who suggests that many MBA programmes are based on values of "competition, individualism, instrumentalism and exclusiveness" (Sinclair, 1995, p. 296). Other work also points to the masculine nature of many programmes (e.g. Mavin \& Bryars, 1999; Simpson, 2000a; Smith, 1997) which, as we have seen, may be largely out of touch with the demands of modern management. This, we argue, may suggest a need to 'feminise' the MBA through more co-operative work and through the encouragement of selfreflection, sharing and exchange so as to deepen emotional learning and mutual support and to 
create a culture that is comfortable and developmental for both men and women.

In terms of course design, this may involve the need to foreground intrinsic benefits and skills beyond the informal context, where these intrinsic elements are largely located, and the adoption of a less 'ad hoc' methodology so that MBA providers take more responsibility for this area of learning. Formalising such processes, for example by giving time and space to critical reflection of individual and team practices, could drive even more powerfully the acquisition of valuable personal and interpersonal skills in a work environment which demands "knowledge for application" or "Mode 2 learning” (Fulmer \& Bernard Keys, 1998, p. 35). In this context, listening, trust building skills and adaptability have been identified as critical to the successful manager and a crucial, though hitherto neglected, component of management education (Martin \& Butler, 2000; Thomson, Maybe, Storey, Gray \& Iles, 2000; Weick, 1999). This may involve a personal development programme which explores underlying attitudes and beliefs that inform a manager's interpersonal ability in relation to colleagues, superiors and clients. In other words, MBA programmes need to provide opportunities for developing emotional intelligence and building better team working, communication and leadership skills as well as opportunities to learn how to 'let go' of unhelpful attitudes and behaviours.

A second and related issue concerns the need to recognise the diversity that exists within MBA programmes. While MBA students remain overwhelmingly young and male (AMBA, 1996), supporting the stereotype of the MBA student as a 'grab it all' young man intent on advancing his career (Dix, 1991), programme developers must avoid any tendency to model their provision on this group alone. This is particularly important if it is young men who fail to fully capitalise on the 'broadening' of the individual and 'life changing' development which Johnson, McLaughlin, Saari and Simmerle (1988) argue are critically important outcomes. As this research has highlighted, motivations, aspirations and the developmental outcomes from the MBA vary with gender and age so that valuable learning opportunities can be lost for all if 
the course methodology favours one albeit dominant group. Older women, for example, may not make effective managers if they lack confidence and assertiveness and may benefit from opportunities to develop these skills and capabilities. Both younger and older men may need help in enhancing skills and attitudes associated with reciprocity and trust. Furthermore, if (as seems to be the case for many students) the MBA is a programme of re-positioning in the world of work and given differences in career orientation by gender and age, then it may be appropriate to include career theory and career development in course content and design. In this way, students can be provided with a framework for the analysis of their own motivations and experiences and can be encouraged to reflect on and perhaps redraw boundaries in terms of what they see as desirable or possible in their future careers. Overall, programme directors need to be aware of how age and gender can influence career orientation as well as attitudes towards and specific requirement from the course.

Finally, business schools need to ensure that they market themselves on intrinsic benefits and interpersonal skills as well as the overt extrinsic benefits and hard skills from the programme (Sturges, Simpson \& Altman, 2003). As we have seen, these intrinsic outcomes are of increasing importance in the new career environment where managing team relationships and interpersonal skills are key to success (Hall \& Mirvis, 1996). In what has been described as a 'saturated' market (Business Week, 2000), MBA providers can gain competitive advantage by marketing and promoting such benefits as key outcomes of the MBA experience and as critical to the professional and managerial career. Overlooking these benefits in promotional and marketing material not only fails to capitalise on an important outcome from the MBA, but may send wrong messages to its students in terms of the priorities of the programme.

\section{CONCLUSION}

This paper set out to explore the nature of extrinsic and intrinsic benefits from the 
MBA and how these might vary by gender. While there has been considerable research on the MBA and career outcomes there has been little research to date on the gendered nature of such outcomes or on the role of the MBA in the acquisition of skills relevant for what has been seen as a new career environment. This study has demonstrated the significance of both gender and age for understanding the benefits of the MBA and for critically evaluating the relevance of MBA programmes. On this basis, findings can be useful in helping to design programmes that meet the needs and wants of men and women in different age groups as well as forming the foundation for future research.

\section{LIMITATIONS}

Several limitations are evident from this study. Firstly, quantitative analysis relied on self report data collected post MBA requiring some reflection on the pre-MBA experience. Such data may be 'distorted' by self justification and personal bias (Baruch \& Peiperl, 2000) as well as by a lack of immediacy to the experience under question. While this may be less problematic in eliciting objective data on career change (e.g. pay/position before and after the MBA), there may be some tendency to overstate the acquisition of more subjective outcomes such as interpersonal skills, leadership capabilities and team working. Secondly, while the data analysis on career change was based on a restricted sample that had graduated between 1997 and 1999 (excluding those who had graduated prior to that time), this does not eliminate the influence of time on career progress. On the one hand, there are likely to be considerable time related variations in career progress within that period. On the other hand, the one-year gap between the survey and completion of the MBA for those who graduated in 1999 may be insufficient for major career changes to be charted. A longitudinal study of MBAs would overcome these time related problems. Finally, unlike the UK study which drew its data from eleven business schools, this Canadian survey has relied on one, albeit large, MBA provider. 
The sample size is, therefore, relatively small and is drawn from a narrow base. Such a sample may well limit the generalizability of the findings beyond this specific research context. The small sample size has also placed constraints on the application of multivariate analysis that might otherwise have disentangled further some of the relationships uncovered. However, as Ibarra (1995) points out, small sample research can provide a foundation for and inform future work. On this basis, this study can be seen to have provided a useful starting point for further inquiry into the relationship between age and gender in orientation towards and outcomes from the MBA. Future studies, particularly with larger samples, can build on and fine-tune these findings. 


\section{REFERENCES}

Altman, Y. (1997). The high-potential fast flying achiever: themes from the English language literature 1976 - 1996. Career Development International, 2 (7), 324 - 329.

Alvesson, M. (1998). Gender relations and identity at work: a case study of masculinities and femininities in an advertising agency. Human Relations, 51 (8), 113-126

AMBA. (1997). Annual Report. London: Association of MBAs

Arthur, M. \& Rousseau, D. (1996) The boundaryless career: a new employment principle for a new organizational era. New York:Oxford University Press.

Baruch, Y. (1999) Response rate in academic studies - a comparative analysis. Human Relations 52 (4), 421-438.

Baruch, Y. \& Peiperl, M. (2000). The impact of the MBA on graduate careers, Human Resource Management Journal, 10 (2), 69-90

Belenky, M., Clinchy, B., Goldberger, N. \& Tarule, J. (1997). Women's ways of knowing: the development of self, voice and mind. New York: Basic Books

Bigg, D., De Ville, B. \& Suen, E. (1991). A method of choosing multiway pathway partitions for classification and decision trees. Journal of Applied Statistics. 18, 49-62

Bishop, R. \& Soloman, E. (1989). Sex differences in career development: locus of control and career commitment effects, Psychological Reports. 35, 107-114

Boyatzis, R. \& Renio, A. (1989). The impact of an MBA programme on managerial abilities. Journal of Management Development, 18 (5), 25-39

Bruce, L. \& Berg, M. (2001). Qualitative research methods for the social sciences, Needham Heights, MA: Allyn and Bacon

Burke, R. \& McKeen, C. (1994). Career development among managerial and professional women. In M. Davidson and R. Burke (Eds.), Women in Management: Current Research Issues (pp. 65-80). London: Chapman.

Burke, R. (1994). Women in corporate management in Canadian organizations: slow progress? Executive Development. 7 (3), 15-24

Business Week (1997) What's an MBA worth? 25, Oct 31

Business Week (2000) Ranking Global Programs 54, Oct 2.

Catalyst. (2000a). 1998 Census of women board directors of Canada. New York: Catalyst. 
Catalyst. (2000b). Women and the MBA: gateway to opportunity. New York: Catalyst.

Cianni, M. \& Wnuk, D. (1997). Individual growth and team enhancement: moving towards a new model of career development. The Academy of Management Executive. 11(1), 105116

Clark, A., Oswald, A. \& Warr, P. (1996) Is job satisfaction U-shaped in age? Journal of Occupational and Organizational Psychology, 69, 57-81

Collinson, D. \& Hearn, J. (2000). Critical studies of men, masculinities and management. In Davidson, M. \& Burke, R. (Eds.), Women in management: current research issue (pp. 263-279). London: Sage

Cox, T. \& Harquil, C. (1991). Career paths and career success in early career stages of male and female MBAs. Journal of Vocational Behaviour: 39, 54-75.

Dix, C. (1991). Enterprising Women, London: Bantam Press.

Ensher, E., Murphy, S. \& Sullivan, S. (2002) Boundaryless careers in entertainment: executive women's experiences, in M. Peiperl, M. Arthur \& N.Anand (Eds.), Career Creativity: Explorations in the Remaking of Work (pp. 229-255). Oxford: Oxford University Press

Evans, P. (1986). New directions in career management. Personnel Management, December, 26-29.

Fondas, N. (1996). Feminization at work: career implications. In M. Arthur \& D. Rousseau (Eds.), The Boundaryless Career (pp. 73-70). New York: Oxford University Press

Fondas, N. (1993). The feminization of American management. In D. Moore (Ed.), Academy of Management Best Paper Proceedings. Atlanta: Academy of Management, 358-362

Fulmer, R. \& Bernard Keys, J. (1998). A conversation with Chris Argyris: The father of organizational learning. Organizational Dynamics. 27(2), 21-33

Gilligan, C. (1982). In a different voice: psychological theory and women's development, Harvard University Press, Cambridge Mass.

Goffee, R. \& Nicholson, N. (1994). Career development in male and female managers convergence or collapse. In R. Burke \& M. Davidson (Eds.), Women in management: current research issues (pp. 80-93). London: Paul Chapman Publishing

Gunderson, M. (1994a). Pay and employment equity in the United States and Canada. International Journal of Manpower, 15 (7), 45-60

Gunderson, M. (1994b). Comparable worth and gender discrimination: international aspects, International Labour Office, Geneva 
Gunz, H., Evans, M. \& Jalland, M. (2000). Career boundaries in a boundaryless world. In M. Peiperl, M. Arthur, R. Goffee. \& T. Morris (Eds.), Career Frontiers (pp. 24-54). New York: Oxford University press.

Hakim, C. (2000). Work lifestyle choices in the $21^{\text {st }}$ century. Oxford:Oxford University Press.

Hall, D. (1976). Careers in organizations, Glenview, IL: Scott Foreman.

Hall, D. (1996). Long live the career: a relational approach. In D. Hall (Ed.), The career is dead, long live the career (pp. 15-30). San Francisco: Jossey Bass

Hall, D. \& Mirvis, P. (1996). The new protean career. In D. Hall (Ed.), The career is dead, long live the career (pp. 63-78). San Francisco: Jossey Bass

Hearn, J. (1994). Changing men and changing management:social change, social research and social action. In M. Davidson \& R. Burke (Eds.), Women in management: current research issues (pp. 192-213). London:Paul Chapman

Heilman, S. (1976). Synagogue life: a study in symbolic interaction. Englewood Cliffs, NJ: Prentice Hall

Hilgert, A. (1998). Professional development of women and the MBA, Journal of Management Development :17(9), 629-643

Hirschman, A. (1970). Exit, voice and loyalty: responses to decline in firms, organizations and the state. Cambridge, Mass: Harvard University Press

Holsti. O. (1968). Content Analysis. In G. Lindzey \& E.Aaronsfield (Eds.), The Handbook of Social Psychology. Reading, MA: Addison Wesley

Ibarra, H. (1993). Personal networks of women and minorities in management, Academy of Management Review, 18, 56-87.

Ibarra, H. (1995). Race, opportunity and diversity of social circles in managerial networks, Academy of Management Journal, 38 (3), 673-703

Institute of Management. 1997. Annual Report. London:IM

Jankowicz, A. 1991. Business research projects for students. London:Chapman and Hall

Jansen, G. \& Davis, R. (1998). Honoring voice and visibility: sensitive-topic research and feminist interpretive inquiry. Affilia Journal of Women and Social Work, 13 (3), 289-302

Johnson, T. McLaughlin, S. Saari, L. \& Simmerle, D. (1988). The demand and supply for university-based executive education. Graduate Management Admission Council, Los Angeles, CA 
Kakabadse, N. \& Kakabadse, A. (1999). Demographics and leadership philosophy:exploring gender differences. Journal of Management Development , 17 (5-6), 351-389

Kanter, R. (1989). The new managerial work. Harvard Business Review. 67 (6), 85-92

Kass, G. (1980). An exploratory technique for investigating large quantities of categorical data. Applied Statistics. 29 (2), 119-127

Kerfoot, D. \& Knights, D. (1993). Management masculinity and manipulation: from paternalism to corporate strategy in financial services in Britain, Journal of Management Studies, 30 (4), 659-77

Kerfoot, D. \& Knights, D. (1998). Managing masculinity in contemporary organizational life: a man(agerial) project, Organization, 5 (1), 7-26

Korman, A., Wittig-Berman, U. \& Lang, D. (1981). Career success and personal failure: alienation in professionals and managers. Academy of Management Journal, 24(2), 342360 .

Kretovics, M. (1999). Assessing the MBA What do our students learn?, Journal of Management Development:18 (2), 125-136

Labour Force Survey.1996. Office for National Statistics. London: HMSO

Labour Force Survey. 2002. Office for National Statistics. London: HMSO

Lee, C. (1994) The feminization of management. Training. November, 25-31

Lynn. S., Cao, L. \& Horn, B. (1996). The influence of career stage on the work attitudes of male and female accounting professionals. Journal of Organizational Behaviour, 17: 135149

Maddock, S. \& Parkin, D. (1994). Gender cultures: how they affect men and women at work. In M. Davidson \& R. Burke (Eds.), Women in management: current research issues (pp. 29-41). London:Paul Chapman

Marks, R., Dugan, M. \& Payn, B. (1997). Why women drop out of graduate management education: answers from GMAC data selections, Graduate Management Admissions Council, Autumn: 6-17

Marshall, J. (1984). Women managers: travellers in a male world, Chichester:Wiley

Marshall, J. (1995). Women managers moving on, London:Routledge.

Martin, G. \& Butler, M. (2000). Comparing managerial careers, management development and management education in the UK and the USA: some theoretical and practical 
considerations. International Journal for Training and Development, 4(3): 196-207

Mavin, S. \& Bryars, P. (1999). Gender on the agenda of management education, Women in Management Review, 14 (3), 99-104

Messmer, M. (1998). The Value of an MBA. Management Accounting. 80 (4) Oct.

Mintzberg, H. \& Gosling, J. (2002). Reality programming for MBAs. Strategy and Business, $26(1), 28-31$

Nicholson, N. \& West, M. (1988). Managerial job change: men and women in transition. Cambridge: University Press.

O'Connor, D. \& Wolfe, D. (1987). On managing mid-life transitions in career and family. Human Relations. 40 (12), 799-816

Ohlott, P., Ruderman, M. \& McCauley, C. (1994). Gender differences in managers' developmental job experiences, Academy of Management Journal. 37 (1), $46-67$.

Pfeffer, J. \& Fong, C. (2002). The end of business schools? Less success than meets the eye, Academy of Management Learning and Education, 1 (1), 78-95

Powell, G. \& Maneiro, L. (1992). Cross-currents in the river of time:conceptualisating the complexities of women's careers. Journal of Management. 18 (2), 215-237

Powell.G. \& Maniero, L. (1993). Getting ahead - in career and in life. In G. Powell (Ed.), Women and Men in Management, $2^{\text {nd }}$ Edition. Newbury Park: Sage

Remenyi, D. (1992). Researching information systems: data analysis methodology using content and correspondence analysis, Journal of Information Technology, 7 (2), 75-90

Ritchie, J. \& Spencer, L. (1994) Qualitative data analysis for applied policy research, in A. Bryman \& R. Burgess (Eds.), Analysing Qualitative Data(pp. 173-195). London: Routledge

Roberts, P. \& Morgan, P. (1987). Levinsonian studies of women's adult development. Psychology and Ageing. 2(2),154-163

Roman, M. (1990). Women beware: An MBA doesn't mean equal pay. Business Week 29:October.

Roth P. L. \& BeVier C. A. (1998). Response rates in HRM/OB survey research: norms and correlates, 1990-1994, Journal of Management Studies 24 (1), 97-117.

Russo, N., Kelly, M. \& Deacon, M. (1991). Gender and sex related attribution: beyond individualistic conceptions of achievement. Sex Roles, 25, 331-350 
Scase, R. \& Goffee, R. (1989). Reluctant managers: their work and lifestyles. London:Unwin Hyman.

Schein, E. (1978). Career dynamics; matching individual and organizational needs, Reading, MA: Addison-Wesley

Schneer, J. \& Reitman, F. (1990). Effects of employment gaps on the careers of MBAs: more damaging for men than women? Academy of Management Journal 33 (2), 392-406.

Schneer, J. \& Reitman, F. (1995). The impact of gender as managerial careers unfold, Journal of Vocational Behaviour, 51, 411-434

Schneer, J. \& Reitman, F. (2003). The promised path: A longitudinal study of managerial careers, Journal of Managerial Psychology, 18 (1/2), 60-75

Shipper. F. (1999). A comparison of managerial skills of middle managers with MBAs, with other masters and undergraduate degrees ten years after the Porter and McKibbin report. Journal of Managerial Psychology, 14(2), 55-70

Silverman, D. (1993) Interpreting qualitative data: methods for analysing talk, text and interaction, London: Sage

Simpson, R. (1995). Is Management Education on the Right Track for Women? Women in Management Review, 10(6), 3-8

Simpson, R. (1996). Does an MBA help women? Gender Work and Organisation, 3(2), 1319

Simpson, R. (2000a). Winners and losers: who benefits most from the MBA. Management Learning, 31(2), 46-54

Simpson, R. (2000b). A voyage of discovery or a fast track to success: men, women and the MBA, Journal of Management Development, 19 (9), 764-782

Simpson, R. \& Altman, Y. (2000). A time bounded glass ceiling: the career progress of young women managers, Journal of European Industrial Training. 24(2,3,4), 190-198

Sinclair, A. (1995). Sex and the MBA. Organization, 2 (2), 295

Smeenk, B. (1993) Canada's pay equity experiments, HRMagazine, 38 (9), 58-62

Smith, C. (1997). Gender issues on management education: a new teaching resource? Women in Management Review, 12 (3), 100-4

Statistics Canada. (1997). Census 1995. Ottawa: Ministry of Industry, Science and Technology

Statistics Canada. (2003). Women in Canada, Ministry of Industry, Science and Technology. 
Sturges, J. (1999). What it means to succeed: personal conceptions of career success held by male and female managers at different ages. British Journal of Management, 10, 239-252

Sturges, J., Simpson, R. \& Altman, Y. (2003). Capitalising on learning: an exploration of the MBA as a vehicle for developing career competencies. International Journal of Training and Development, 7 (1), 53-67

Subich, L., Barret, G., Doverspike, D. \& Alexander, R. (1989). The effects of sex role related factors on occupational choice and salary. In R. Hartmann and B. O'Farrell (Eds.), Pay Equity: Empirical Inquiries (pp. 83-102). Washington DC: National Academy Press

Summers, T. (1988). Examination of sex differences in expectations of pay and perceptions of equity in pay. Psychological Reports, 62, 491-496.

Thomson, A., Maybe,C., Storey, J., Gray, C. \& Iles. P. (2000). Changing Patterns of Management Development, Oxford: Blackwell

Wallace, P. (1989). MBAs on the fast track: the career mobility of young managers, New York: Ballinger.

Weick, K., Mintzberg, H. \& Senge, P. (1999). Transforming Management Education for the $21^{\text {st }}$ Century, Symposium conducted at the Annual Conference for the Academy of Management, Chicago.

Young, B., Worchel, S. \& Woehr, D. (1998). Organizational commitment among public service employees. Public Personnel Management. 27 (3), 339-349 
Table 1: Motivations for taking the MBA by Gender and Age (\%).

\begin{tabular}{|l|l|l|l|l|l|}
\hline & $\begin{array}{l}\text { Younger } \\
\text { men } \\
\text { under35) }\end{array}$ & $\begin{array}{l}\text { Younger } \\
\text { women } \\
\text { under35) }\end{array}$ & $\begin{array}{l}\text { Older men } \\
(35 \text { or more })\end{array}$ & $\begin{array}{l}\text { Older women } \\
(35 \text { or more })\end{array}$ & Total \\
\hline $\begin{array}{l}\text { Improve job } \\
\text { opportunities }\end{array}$ & 50.0 & 28.6 & 36.9 & 53.6 & 41.3 \\
\hline $\begin{array}{l}\text { Change career } \\
\text { direction }\end{array}$ & 23.4 & 38.8 & 16.9 & 21.4 & 24.8 \\
\hline $\begin{array}{l}\text { Obtain business } \\
\text { qualification }\end{array}$ & 12.5 & 22.4 & 18.5 & 17.9 & 17.5 \\
\hline $\begin{array}{l}\text { Intellectual } \\
\text { stimulation }\end{array}$ & 14.1 & 10.2 & 27.7 & 7.1 & 16.5 \\
\hline $\mathrm{N}$ & 64 & 49 & 65 & 28 & 206 \\
\hline
\end{tabular}

Chi square: $19.557, \mathrm{P}=0.021$

Table 2: Career Progress of MBA graduates by gender and Age (\%)

\begin{tabular}{|l|l|l|l|l|l|}
\hline Progress & $\begin{array}{l}\text { Younger men } \\
\text { (under 35) }\end{array}$ & $\begin{array}{l}\text { Younger } \\
\text { women } \\
\text { (under 35) }\end{array}$ & $\begin{array}{l}\text { Older men } \\
(35 \text { and over })\end{array}$ & $\begin{array}{l}\text { Older women } \\
(35 \text { and over })\end{array}$ & Total \\
\hline $\begin{array}{l}\text { Same } \\
\text { function }\end{array}$ & 21.2 & 25.0 & 33.9 & 39.1 & 28.0 \\
\hline $\begin{array}{l}\text { Different } \\
\text { function }\end{array}$ & 25.8 & 18.8 & 42.9 & 21.7 & 28.5 \\
\hline $\begin{array}{l}\text { Sideways } \\
\text { change }\end{array}$ & 12.1 & 10.4 & 5.4 & 8.7 & 9.3 \\
\hline $\begin{array}{l}\text { Set up own } \\
\text { business }\end{array}$ & 4.5 & 4.2 & 7.1 & 8.7 & 5.7 \\
\hline $\begin{array}{l}\text { Change } \\
\text { career }\end{array}$ & 33.3 & 20.8 & 7.1 & 17.4 & 20.7 \\
\hline No change & 3.0 & 20.8 & 3.6 & 4.3 & 7.8 \\
\hline N & 66 & 48 & 56 & 23 & 193 \\
\hline
\end{tabular}

Chi square: $35.881, \mathrm{P}=0.002$ 
Table 3: Pay after the MBA by Gender and Age (\%)

\begin{tabular}{|l|l|l|l|l|}
\hline $\begin{array}{l}\text { Pay (Canadian } \\
\text { Dollars) }\end{array}$ & $\begin{array}{l}\text { Younger men } \\
\text { (under 35) }\end{array}$ & $\begin{array}{l}\text { Younger } \\
\text { women } \\
\text { (under 35) }\end{array}$ & $\begin{array}{l}\text { Older men } \\
(35 \text { and over })\end{array}$ & $\begin{array}{l}\text { Older women } \\
(35 \text { and over })\end{array}$ \\
\hline $\begin{array}{l}\text { Category 1 } \\
\text { Under \$60k }\end{array}$ & 6.0 & 22.7 & 0 & 4.3 \\
\hline $\begin{array}{l}\text { Category 2 } \\
\$ 60-100 \mathrm{k}\end{array}$ & 58.2 & 45.5 & 30.2 & 60.9 \\
\hline $\begin{array}{l}\text { Category 3 } \\
\text { Over \$100k }\end{array}$ & 35.8 & 31.8 & 69.8 & 34.8 \\
\hline $\mathrm{N}$ & 67 & 44 & 53 & 23 \\
\hline
\end{tabular}

Chi square: $33.577, \mathrm{P}=0.000$

Table 4: Career benefits of the MBA (reporting the benefit 'to a great extent').

\begin{tabular}{|l|l|c|l|}
\hline Main Benefits & Number & \% & Significant effects \\
\hline Greater marketability/mobility & 100 & 45.7 & \\
\hline Enhanced job prospects & 82 & 37.4 & \\
\hline Enhanced salary or status & 66 & 30.1 & $*$ age, age/gender \\
\hline Enhanced confidence & 56 & 25.6 & $*$ age \\
\hline Enhanced credibility & 58 & 26.4 & $*$ age/gender \\
\hline Higher levels of job satisfaction & 25 & 11.4 & \\
\hline Greater interpersonal skills & 14 & 6.4 & \\
\hline
\end{tabular}

Table 5: Perception of skills acquired from the MBA (reporting the skill 'to a great extent')

\begin{tabular}{|l|c|c|c|}
\hline Main skills & Number & \% & Significant effects \\
\hline Handle and analyse complex data & 44 & 20.0 & \\
\hline Improved negotiation skills & 27 & 12.3 & \\
\hline More effective at meetings & 26 & 11.9 & \\
\hline Manage individuals/teams more effectively & 25 & 11.4 & \\
\hline More assertive in my dealings with others & 23 & 10.4 & $*$ Age/gender \\
\hline Work more effectively with others & 22 & 10.0 & \multicolumn{2}{|c|}{} \\
\hline More sensitive to difference and diversity & 9 & $4.12^{*}$ Age \\
\hline
\end{tabular}


